\title{
Planning for the Return of Separated Children Seeking Asylum: An Inter-Country Social Service Perspective
}

\author{
Sarah Crowe
}

\begin{abstract}
A variety of circumstances contribute to an increasingly large number of minors who leave family, home, and country to seek asylum on foreign soil. They present special challenges to state and local authorities, to relevant non-governmental agencies, and to the international community. This paper considers the planning needs for these minors for whom asylum is denied and for whom return to country of origin needs to be arranged. The paper highlights the need for a social service perspective, such as provided by International Social Service, to be included in the planning process.
\end{abstract}

\section{Résumé}

Des circonstances très variées contribuent au fait qu'un nombre croissant de mineurs abandonnent leurs familles, leur patrie et leur pays pour aller chercher asile dans un pays étranger. Ils posent des défis particuliers aux autorités locales et nationales, aux organismes non-gouvernementaux et à la communauté internationale. Cet article examine les besoins au niveau de la planification pour pouvoir aider ceux de ces mineurs qui se voient refuser le droit d'asile et pour qui on doit faire des arrangements pour leur retour dans leur pays d'origine. L'article souligne la nécessité d'adopter, dans le processus de planification, une approche des services sociaux, comme par exemple celle de Service Social International.

\section{Introduction}

A the world becomes increasingly globalized and new $\Lambda$ migration patterns emerge, the phenomenon of escalatLing numbers of separated minors seeking safe havens or
asylum requires special consideration by the relevant authori- ties. ${ }^{1}$ While states have always seen the arrival of separated or unaccompanied minors, the new challenge is both to manage the large numbers of minors and to provide a range of services to ensure their safety, well-being, and basic human rights. Many of these children have escaped war, civil strife, economic hardship, and uncertain futures. Others have left on their own initiative or with parental assisted exile, with the result that many have become victims of trafficking, smuggling, and exploitation. Many of these children arrive with high expectations, not realizing that the countries in which they are seeking to live have established barriers which can place them at risk of marginalization and continued hardship. These minors have experienced anxiety in leaving their family and home country, trauma from their travel, and uncertainty upon arrival. They are children without legal status or guardians. They are children at risk and in need of protection. Ultimately, a decision will be made for each of these minors: they will be granted legal status in the host country or receiving country; they will receive temporary humanitarian refugee permits; they will be reunified with family members in other countries; or they will be returned to their country of origin.

This paper will consider the planning needs for minors whose asylum is denied or for whom repatriation is determined to be in their best interest. A social service perspective needs to be part of the planning, as it can provide governments and relevant authorities with information and support mechanisms, and can help implement the return of these children to their country of origin and the provision of follow-up services when their asylum claims are denied. International Social Service (ISS) is an international NGO dedicated to assisting children and families in migration. From an historical 
perspective, ISS experience in dealing with separated minors demonstrates that the safe and properly planned return of children is possible to effect.

\section{Planning Considerations}

For minors whose asylum claim is denied, planning for their return needs to be completed with care, sensitivity, and with their best interest as the primary consideration. Returning minors to their country of origin can be expected to create high anxiety, a sense of failure, and a loss of hope for their future. The need for inter-country co-operation is essential in planning for the return of separated minors seeking asylum. ${ }^{2}$ For some children, migration return may be relatively uncomplicated. The family welcomes their return and it is safe to return. For others, however, return migration is highly stressful and traumatizing. Guided by the principles outlined in the Convention on the Rights of the Child (CRC) and the guidelines in UNHCR and Save the Children's Separated Children in Europe Programme Statement of Good Practice, the international community is called upon from both a policy standpoint as well as at a practice level to provide the resources necessary to respond to children's safety and well-being. Many issues need to be addressed. When should the planning for returns begin? What considerations should be made to contact the family in the country of origin? How should it be facilitated? What services need to be in place to assist the minor for possible return? Should responsibility for these children extend beyond the return of a child to his/her country of origin? How can the minor be helped to return with a sense of security and possibilities for the future? Could a risk assessment, as well as a follow-up procedure, be in place to ensure the safety of asylumseeking children who are found to be ineligible to remain in the country of destination? Co-operation between immigration authorities and competent child welfare authorities and the relevant non-governmental organizations (NGOs) is essential in addressing the needs and issues concerning these separated minor asylum-seekers.

\section{An ISS Perspective: An Individual Approach}

International Social Service (ISS) came into being as a result of vast migration following WWI. This organization has been involved with cases relating to separated minor asylum seekers since its origins in 1924. Emerging from the crises of these migrations, through their social work focus for wartime refugees, ISS adopted a vision of "offering help to people regardless of race, creed or political affiliation, who are suffering and facing difficulties caused by moving from one country to another." ${ }^{3}$ More specifically, ISS casework consists primarily of issues concerning children. The development of ISS led to international social services sensitive to linguistic, cultural, and social issues with an international perspective in terms of family laws, divorce laws, and immigration laws. ${ }^{4}$

ISS demonstrates a competent capacity to offer leadership particularly due to its inter-country experience and international network to improve the processes of care for these children at risk. Through its historical and international experience, ISS has always been very involved in the planning for the best interest of separated minors. For example, the government of the United Kingdom funded an ISS UK-led program in response to the needs of minors migrating from the Yugoslavian conflict in the 1990s. This program ran for three consecutive years and worked with hundreds of minors from Bosnia, Albania, and Kosovo. ${ }^{5}$

Another example, although not involving the return of separated minors, demonstrates ISS involvement in responding to national crises. In 1995, following the war and genocide in Rwanda, a program was developed in order to find the best solutions to help orphaned Rwandan children. ${ }^{6}$ Where family reunification was impossible, the program intended to integrate orphaned children into Rwandan foster families. The objective was to ensure that these orphaned or separated children would grow up in a safe, stable family environment despite their separation from their birth parents. This program, whereby some 916 children were placed into families by the end of October 2001, proved to be successful. ${ }^{7}$ Indeed, social work expertise with an international focus can provide various solutions for separated minors and plan in their best interests.

\section{Establishing "Best Interest"}

Article 3.1 of the CRC establishes the principle of best interest as a primary consideration by all relevant competent authorities. ${ }^{8}$ Many child advocates use this principle to compel states to reflect upon their policies and practices involving the care of children. The growing phenomenon of child refugees separated from their parents or legal guardian further challenges our capacities to ensure the human rights and welfare that children are entitled to vis-à-vis international conventions. From an ISS perspective, the planning and organization for return as well as follow-ups and family assessments are of particular concern. These principles, to be followed when planning the return of a child to his or her country of origin, identify the means by which "best interest" is considered throughout the process.

Save the Children and UNHCR's Separated Children in Europe Programme Statement of Good Practice outlines practices that should be followed in order to comply with the relevant international conventions. Tracing the fam- 
ily is crucial in understanding and ensuring best interest of separated minor asylum seekers." Accordingly, the "good practice" suggests that family tracing and family reunification are deeply rooted in the rights and entitlements specific to children.10 When assessing the situation, therefore, the host country should consider family reunification as a primary consideration.

The safe return of children to their country of origin is established in Section 12.2.2 (a) of the Separated Children in Europe Programme Statement of Good Practice. These guidelines require the guardian in the host country to arrange for appropriate investigations and social assessments to be conducted in order to help establish whether it is in the child's best interest to return. It is also deemed essential that contact be established between the child and family of origin and that the child is properly accompanied on the return. Furthermore, it is expected that follow-up monitoring services will be provided by a designated NGO or international organization. ${ }^{11}$ The Italian government, for example, has developed a program for the repatriation of children that combines socio-economic reintegration with a sensitive focus on cultural and family situations. In essence, under Italian immigration law, children are returned to their families not only with careful preparation but also with long-term solutions. The Italian model, with the challenge of large numbers of separated minors arriving in Italy, illustrates how these principles can be upheld in practice.

\section{The Italian-Albanian Model}

Beginning in 1989 with the fall of the Communist regime, a massive flow of Albanian refugees arrived in Italy. The 1991 exodus of thousands of Albanian minors (some with family, others without) dispersed across Italy without a system to care for their well-being. During that time, about twelve thousand Albanian citizens claimed asylum in Italy, or whom nearly 600 were granted said status. This led the authorities in Italy to examine their procedure for dealing with the care and guardianship of separated minors. ${ }^{12}$ This phenomenon intensified in 1997 following an economic and political crisis in Albania leading to another exodus to Italy. This second exodus was characterized by the presence of many separated minors. Many of these minors, who were repatriated by the Italian authorities, were found to flee back to Italy several times, despite their many repatriations. It was observed that these minors arrived in Italy as though through a "revolving door." The Italian authorities often involved the Italian Branch of International Social Service (ISS Italy) in order to plan for the return of these children. In fact, in 1991 the Italian Branch had established an Albanian Delegation of the ISS. It had been set up in order to deal with all social cases related to emigration, broken families as well as minors. Subsequently, the work of the Albanian delegation became increasingly focused on the problems of separated minors. These minors' principal motive for fleeing Albania was complete uncertainty with respect to their future prospects. Thus, it was clear that an approach to remedy this problem would consider the establishment and insurance of a credible future for these children in Albania to motivate them to remain at home.

The 1997 exodus led to government funding and support of programs in Italy to manage the arrival of these Albanian minors. The program led by ISS Italy focused on family investigations (home assessments), opportunities for reunification, and repatriation facilitating reintegration into Albanian society. Although this program exclusively served Albanian minors, the authorities involved hoped to export the Albanian experience to other countries both of origin and of exile. ${ }^{13}$ This program proved successful in Italy although it was observed that an improved system for reintegration would further benefit these minors and prevent their return to Italy despite repatriation. ${ }^{14}$

Subsequent to the concerns brought forth by the authorities involved in the program for Albania was the signing of a Convention between ISS Italy and the Government Committee for the Protection of Minors. This Convention was based on the principles outlined in the $\mathrm{CRC}$ as well as recent national and international legislation focused on children's rights to live in their family and in their culture. ${ }^{15}$ Furthermore, this Convention bridged the gap between the obligation of immigration authorities to evaluate refugee status and welfare authorities' concerns for protective care and guardianship. Operational as of April 30, 1998, the following provisions apply:

1. the technical organization of repatriation voyages, including individual examinations and assessments of every case;

2. placement of repatriated minors in professional courses, job training, or apprenticeships in Albania, an action which would entail the assistance and participation of Albanian professional institutes and organizations active in the area;

3. the gathering of statistical data relative to separated Albanian minors in Italy reported to the Comité pour la Protection des Mineurs Étrangers or to ISS Italy;

4. the analysis and interpretation of information acquired, in order to prevent departures, and improve the reception and support the repatriations. ${ }^{16}$

Initially, the Convention was to expire after one year. However, due to its success, it was renewed on January 1, 2000. Furthermore, in March 2001, a new Convention was signed seeking to expand this process of repatriation to all separated minors in Italy regardless of their nation- 
ality. ${ }^{17}$ Between 1998 and 1999, approximately 160 repatriated Albanian minors were integrated into professional courses or apprenticeships. Of these minors, 12 abandoned their classes; 94 pursued their classes; 55 completed and were employed in independent or salaried work. In 2000, a follow-up of the program determined that 47 families were successfully reunified. ${ }^{18}$ ISS Italy is presently seeking to expand this program to other countries, namely, Romania, Moldavia, and Morocco.

The Italian-Albanian experience demonstrates that through collaboration and leadership the proper mechanisms can be put in place to assist governments and meet their obligations to uphold the rights of children. Working from the principle that the family is the most important element to a child's development, social assessments and family involvement are essential to the repatriation process. Indeed, the Italian model effectively ensures that the best interest of the minors is held as the primary consideration.

\section{"An Ounce of Prevention Is Worth a Pound of Cure"} From an optimistic viewpoint, it is becoming increasingly evident that states, care authorities, immigration authorities, and NGOs acknowledge the seriousness of the issues concerning separated minor asylum-seekers. Although countries are not necessarily compliant with the principles outlined in the international conventions to which they are members, many states have ratified or are in the process of ratifying international and national legislative principles of care concerning the return of these minors. For example, the European Union (EU) Council Resolution 97/C 221/03 of June 26, 1997 compels all EU member countries to transform into national law by January 1, 1999, guidelines for the treatment of separated minor asylum seekers. ${ }^{19}$ With respect to return, for example, article 5.1 states that minors shall only be returned to their country of origin after the conditions of such a return are clarified. ${ }^{20}$ The EU hereby recognizes the necessity and importance of ensuring the safety and well being of separated children asylum-seekers.

Another example of this trend is a project guided by ISS Switzerland evaluating and assisting the safe and social-economic return of separated minor asylum-seekers. Similar to the Italian experience, ISS Switzerland, through its professional resources as well as international partnerships, is proposing to find concrete solutions for the assistance for return and re-integration in the country of origin. ${ }^{21}$ The proposals for this project include:

a. Ensuring a return to a safe environment while offering programs for future prospects based on individual evaluations;

b. Ensuring equal protection to refugee children as to Swiss children;

c. From individual as well as national studies, planning for long term solutions; d. Giving priority to family reunification;

e. Where family reunification is not possible, providing the care necessary for the development of the child;

f. And preparing objective and targeted information to the countries of origin in the attempt to prevent parents from sending their children with false hope to Western countries. ${ }^{22}$

From an ISS perspective, planning for the return not only to a safe environment but also with a re-integration in the economic, social and family framework is crucial. Through careful examination of individual as well as national cases, a dissemination of information could assist in prevention programs and demonstrate to families the potential risks and dangers for children upon departure to a foreign country.

In October 2001, UNHCR, Child Welfare League of Canada, and ISS Canada hosted a National Roundtable on the topic of "Separated Minors Seeking Asylum in Canada." This Roundtable brought together immigration authorities, child welfare authorities, NGOs and child advocates from across the country to discuss the present situation affecting these minors and the different federal and provincial procedures involved. Communication between these key players involved in issues concerning separated minors seeking asylum in Canada is vital to planning for the best interest of these children. The Roundtable was a stepping-stone to developing cooperation between the child welfare authorities responsible for care and guardianship, and the immigration authorities responsible for establishing status in pursuit of a national framework to deal with separated children claiming asylum in Canada. Enabling the safe return to the country of origin can be complicated due to original conditions upon flight, and security conditions in the country. Anticipation for the return to the conditions a child has fled can be expected to further stress and traumatize a child. Social work expertise, on an individual, case-by-case basis, with an international focus would offer a link across borders for the necessary services required such as home assessments for both planning for return, and search for family information. The discussions during the Roundtable were a positive development for reflection upon Canada's experience with these children at risk.

\section{Conclusion}

Global conditions of war, civil strife, and poor economic conditions motivate the migration and cause the displacement of many peoples around the world. Within this group, children are the most vulnerable. When chil- 
dren arrive, separated from their family at the borders of countries of destination, they have already experienced the trauma not only from former living conditions but also from leaving their family. These separated minors claiming asylum are children at risk. Their vulnerability is reflected in international conventions that state that children should be provided with care regardless of nationality, culture, or religion. ${ }^{23}$ Observing the experience from the European Community dealing with a large exodus of separated minors, much can be learned from organized co-operation among the authorities and NGOs involved. In particular, the Italian model developed for the safe return of Albanian minors demonstrates that the organization of long-term solutions for large numbers of separated minors can be facilitated with an individual approach. This model abides by the principles set forth in the CRC as well as in the Separated Children in Europe Programme Statement of Good Practice. Indeed, an international non-governmental organization, such as ISS, provides governments, child welfare authorities, and immigration authorities with the necessary inter-country network needed to plan for these minors. From this perspective, with the proper leadership, co-operation, and understanding, the mechanisms can be organized to ensure the safety, well being, and basic human rights of these children at risk.

\section{Notes}

1. Throughout this essay, the terms "children" and "minors" will be used interchangeably and will be defined as human beings under the age of eighteen as per article 1 of the Convention on the Rights of the Child (With Reservations and Statement of Understanding), 20 November 1989, Can T.S. 1992 No.3 [hereinafter $C R C]$.

2. The definition of "separated minors" is as follows: "Separated children and young people' are children under 18 years of age who are outside their country of origin and separated from both parents, or their legal/customary primary caregiver," Save the Children and UNHCR, Separated Children in Europe Programme Statement of Good Practice, 1999, s. 2.1 [hereinafter SGP].

3. Audrey E. Moser, "Young People in Migration: A Challenge for Social Services," in Young People in Migration: A Challenge for Social Services." Report on the International Social Service "Open Day" of 25 May 2000, 2.

4. Ibid., 5.

5. Ibid., 19.

6. "'A Child, A Family,' in Rwanda." International Programs and Projects. On-line: <http://www.iss-ssi.org/eng/ ISS_prog.html>. Date accessed: 23 November 2001.

7. Moser, 19.

8. CRC, art. 3 .

9. Article 9.3 of the CRC states that "States Parties shall respect the right of the child who is separated from one or both parents to maintain personal relations and direct contact with both parents on a regular basis, except if it is contrary to the child's best interest" (CRC, art. 9).
10. SPG, ss. 8 and 9.

11. SPG, s. 12.2.2 (a)

12. Servizio Sociale Internatiozionale - ONLUS (Sezione Italiana). «Rapatriement assiste des mineurs non accompagnés : l'expérience du Service Social International en Albanie. » Synthèse du rapport sur le programme mis en oeuvre par le Service Social International en Italie et en Albanie durant les années 1998 et 1999 et mise a jour an 2000, p. 1. [Hereinafter ISS Italy].

13. ISS Italy, 2.

14. ISS Italy, 2.

15. Article 9.1 of the CRC states that: "States Parties shall ensure that a child shall not be separated from his or her parents against their will, except when competent authorities subject to judicial review determine, in accordance with applicable law and procedures, that such separation is necessary for the best interests of the child..." (CRC, art. 9).

16. ISS Italy, $2-3$.

17. ISS Italy, 4.

18. ISS Italy, 8.

19. COUNCIL RESOLUTION of 26 June 1997 on unaccompanied minors who are nationals of third countries (97/C 221/03), on-line: <http://www.unhcr.bg/euro_docs/en/ _32_minors_en.pdf> (date accessed: 21 November 2001). [hereinafter Resolution 97/C 221/03].

20. Article 5.1 states that: "Where a minor is not allowed to prolong his stay in a Member State, the Member State concerned may only return the minor to his country of origin or a third country prepared to accept him, if on arrival therein - depending on his needs in the light of age and degree of independence - adequate reception and care are available. This can be provided by parents or other adults who take care of the child, or by governmental or non-governmental bodies" (Resolution 97/C 221/03).

21. Service Social International Fondation Suisse, "Evaluation et aide au retour pour des réfugiés mineurs non accompagnés. MNA." Geneva: SSI Fondation Suisse, 30 October, 2000) [Hereinafter ISS Switzerland].

22. ISS Switzerland, 2.

23. CRC, art. 2.

Sarah Crowe is a graduate in political studies from Queen's University, Kingston, Ontario. Presently, Sarah is working as a volunteer researcher at International Social Service Canada. Special recognition is given to Agnes Casselman, Executive Director of ISS Canada, for her guidance and assistance. Special consideration also goes to Damien Ngabonziza, Secretary General, ISS General Secretariat, Geneva, Switzerland, and to Anna Libri, Assistant Director of ISS Italy, for their review and helpful comments. 